\title{
Geographic distribution and habitat use of Lepidoblepharis miyatai (Squamata: Sphaerodactylidae), with comments on the taxonomic status of the genus in northern Colombia
}

Andrés Camilo Montes-Correa, ${ }^{1}$ Juan David Jiménez-Bolaño, ${ }^{1}$ Guido Fabián Medina-Rangel,, 3 Gilson A. Rivas, ${ }^{4}$ Hernán D. Granda-Rodríguez, ${ }^{5,6}$ Liliana P. Saboyá-Acosta, ${ }^{1,7,8}$ and Juan Manuel Renjifo ${ }^{1}$

${ }^{1}$ Grupo de Investigación en Manejo y Conservación de Fauna, Flora y Ecosistemas Estratégicos Neotropicales (MIKU), Universidad del Magdalena, Santa Marta, Colombia. E-mail: andresc.montes@gmail.com.

${ }^{2}$ Reptiles-Grupo de Biodiversidad y Conservación, Instituto de Ciencias Naturales, Universidad Nacional de Colombia, Bogotá, Colombia.

${ }^{3}$ Grupo de Biodiversidad y Sistemática Molecular, Instituto de Ciencias Naturales, Universidad Nacional de Colombia, Bogotá, Colombia.

${ }^{4}$ Museo de Biología, Facultad Experimental de Ciencias, Universidad del Zulia, Maracaibo, Venezuela.

${ }^{5}$ Programa de Postgrado en Áreas Silvestres y Conservación de la Naturaleza, Facultad de Ciencias Forestales y de la Conservación de la Naturaleza, Universidad de Chile, Santiago, Chile.

${ }^{6}$ Programa de Biología, Facultad de Ciencias Básicas, Universidad del Magdalena, Santa Marta, Colombia.

${ }^{7}$ Programa de Doctorado en Estudios Ambientales y Rurales, Facultad de Estudios Ambientales y Rurales, Pontificia Universidad Javeriana, Bogotá D.C., Colombia.

${ }^{8}$ EDGE of Existence Fellowship, Zoological Society of London.

\begin{abstract}
Geographic distribution and habitat use of Lepidoblepharis miyatai (Squamata: Sphaerodactylidae), with comments on the taxonomic status of the genus in northern Colombia. We present some ecological and biogeographic data on Lepidoblepharis miyatai, a small and endangered gecko endemic to the northwestern foothills of the Sierra Nevada de Santa Marta (SNSM), 31 years after its description. Based on museum specimens and field observations, we recorded four new localities with confirmed presence of $L$. miyatai. We calculated the extent of occurrence and altitudinal distribution of this species reaching $21.3 \mathrm{~km}^{2}$ and from sea level to $360 \mathrm{~m}$ respectively. Lepidoblepharis miyatai inhabits plant formations of scrub thorn and tropical deciduous forest. Based on microhabitat data obtained from 88 individuals observed in "Las Tinajas Village" we can state a differential use of three substrates with predominant use of leaf-litter. We consider $L$. miyatai an endemic species of the northwestern sector of the SNSM with a distribution range limited to the south-west by the occurrence of $L$. sanctaemartae, and towards the east by a thus far undetermined Lepidoblepharis species (here called Lepidoblepharis cf. sanctaemartae). We do not register sympatry of L. miyatai with any other congener. Accordingly, we consider that the recent records of this species in the southeast sector of
\end{abstract}

Received 22 August 2017

Accepted 28 May 2018

Distributed June 2018 
SNSM are erroneous, given that the specimens cited as L. miyatai of this zone correspond to Lepidoblepharis cf. sanctaemartae. Finally, a reevaluation of the conservation status of L. miyatai is needed, including precise information of its distribution.

Keywords: conservation, Gekkota, Lepidoblepharis sanctaemartae, Sierra Nevada de Santa Marta, substrate use, Tayrona National Park, tropical dry forest.

\begin{abstract}
Resumen
Distribución geográfica y uso de hábitat de Lepidoblepharis miyatai (Squamata: Sphaerodactylidae) con comentarios sobre la taxonomía del género en el norte de Colombia. Presentamos algunos datos ecológicos de Lepidoblepharis miyatai, un pequeño y amenazado gecko endémico de las estribaciones noroccidentales de la Sierra Nevada de Santa Marta (SNSM) 31 años después de su descripción. Con base a ejemplares depositados en colecciones y observaciones en campo, registramos cuatro nuevas localidades con presencia confirmada de L. miyatai. Calculamos la extensión de ocurrencia y la distribución altitudinal de esta especie con las localidades presentadas, alcanzando un área de $21.3 \mathrm{~km}^{2}$ y un rango altitudinal entre el nivel del mar y los $360 \mathrm{~m}$. Esta especie está presente en formaciones de matorral espinoso y bosque seco. Con la información de microhábitat obtenida de 88 individuos registrados en "Las Tinajas", determinamos que esta especie presenta uso diferencial de los tres tipos de sustrato que ocupa, utilizando principalmente la hojarasca. Consideramos a este lagarto como endémico del sector noroccidental de la SNSM, limitando hacia occidente con el rango de distribución de Lepidoblepharis sanctaemartae y hacia oriente con una especie de Lepidoblepharis hasta ahora no determinada (denominada aquí como Lepidoblepharis cf. sanctaemartae). No registramos simpatría de L. miyatai con alguno de estos congéneres. De igual manera, consideramos que los registros recientes de esta especie en el sector suroriental de la SNSM son erróneos, dado a que los ejemplares citados previamente como L. miyatai en esta zona corresponden con Lepidoblepharis cf. sanctaemartae. Finalmente, se hace necesaria una reevaluación del estado de conservación de L. miyatai, donde se incluya la información más precisa de su distribución.
\end{abstract}

Palabras clave: Bosque seco tropical, conservación, Gekkota, Lepidoblepharis sanctaemartae, Parque Nacional Natural Tayrona, Sierra Nevada de Santa Marta, uso de sustrato.

\title{
Resumo
}

Distribuição geográfica e uso de hábitat de Lepidoblepharis miyatai (Squamata: Sphaerodactylidae) com comentários sobre a taxonomia do gênero no norte da Colômbia. Apresentamos alguns dados ecológicos de Lepidoblepharis miyatai, um pequeno lagarto ameaçado endêmico das encostas norteocidentais da Sierra Nevada de Santa Marta (SNSM) 31 anos após sua descrição. Com base em exemplares depositados em coleções e observações de campo, registramos quatro novas localidades com presença confirmada de L. miyatai. Calculamos a extensão de ocorrência e a distribuição altitudinal dessa espécie com as localidades apresentadas, alcançando uma área de $21.3 \mathrm{~km}^{2}$ e uma variação altitudinal do nível do mar a $360 \mathrm{~m}$. Essa espécie está presente em formações de bosque espinhoso e de floresta tropical decídua. Com informações sobre o uso de micro-hábitats obtidas de 88 indivíduos registrados em "Las Tinajas", determinamos que essa espécie apresenta uso diferencial dos três tipos de substrato que ocupa, utilizando principalmente a serapilheira. Consideramos esse lagarto como endêmico do setor norte-ocidental de SNSM, com sua distribuição limitada a sudoeste pelo contato com Lepidoblepharis sanctaemartae e a leste com uma espécie indeterminada de Lepidoblepharis (aqui denominada Lepidoblepharis cf. sanctaemartae). Não registramos simpatria de L. miyatai com nenhuma dessas espécies congêneres. Do mesmo modo, consideramos errôneos os registros recentes dessa espécie no setor sul-oriental de SNSM, já que os exemplares citados previamente como L. miyatai nessa zona correspondem a Lepidoblepharis cf. sanctaemartae. Finalmente, se faz necessária uma reavaliação do estado de conservação de L. miyatai que incluam informações mais precisas sobre sua distribuição.

Palavras-chave: conservação, floresta tropical decídua, Gekkota, Lepidoblepharis sanctaemartae, Parque Nacional Natural Tayrona, Sierra Nevada de Santa Marta, uso de substrato. 


\section{Introduction}

Twelve species of Lepidoblepharis Peracca, 1897 have been recognized in Colombia, being the country with the highest diversity of the genus, where only two of them are present in the Caribbean lowlands (Ayala and Serna 1986, Calderón-Espinosa and Medina-Rangel 2016). However, the knowledge about the taxonomic status, geographic distribution, and natural history of most Lepidoblepharis is poor, with some species been known only from their types and the original description (Ayala 1986). One of them Lepidoblepharis miyatai Lamar, 1985 (Figure 1), is a small and endangered gecko, which went unnoticed for over five decades. Its original description was based on seven specimens collected in 1964 in Ensenada Gairaca (Gairaca Bay), Tayrona National Park (TNP), a locality enclosed by the northwestern foothills of the Sierra Nevada de Santa Marta (Santa Marta Mountains; SNSM). This isolated massif is located in northeast Colombia close to the Caribbean Sea, and is considered an ecogeographical region of high endemicity (Lynch et al. 1997, Armesto and Señaris 2017). The presence of L. miyatai on the southeastern foothills of the SNSM has been also recently recorded some 125 $\mathrm{km}$ southeast of the type locality (CalderónEspinosa and Medina-Rangel 2015). As far as we know, L. miyatai is endemic to the SNSM foothills (Carvajal-Cogollo et al. 2012).
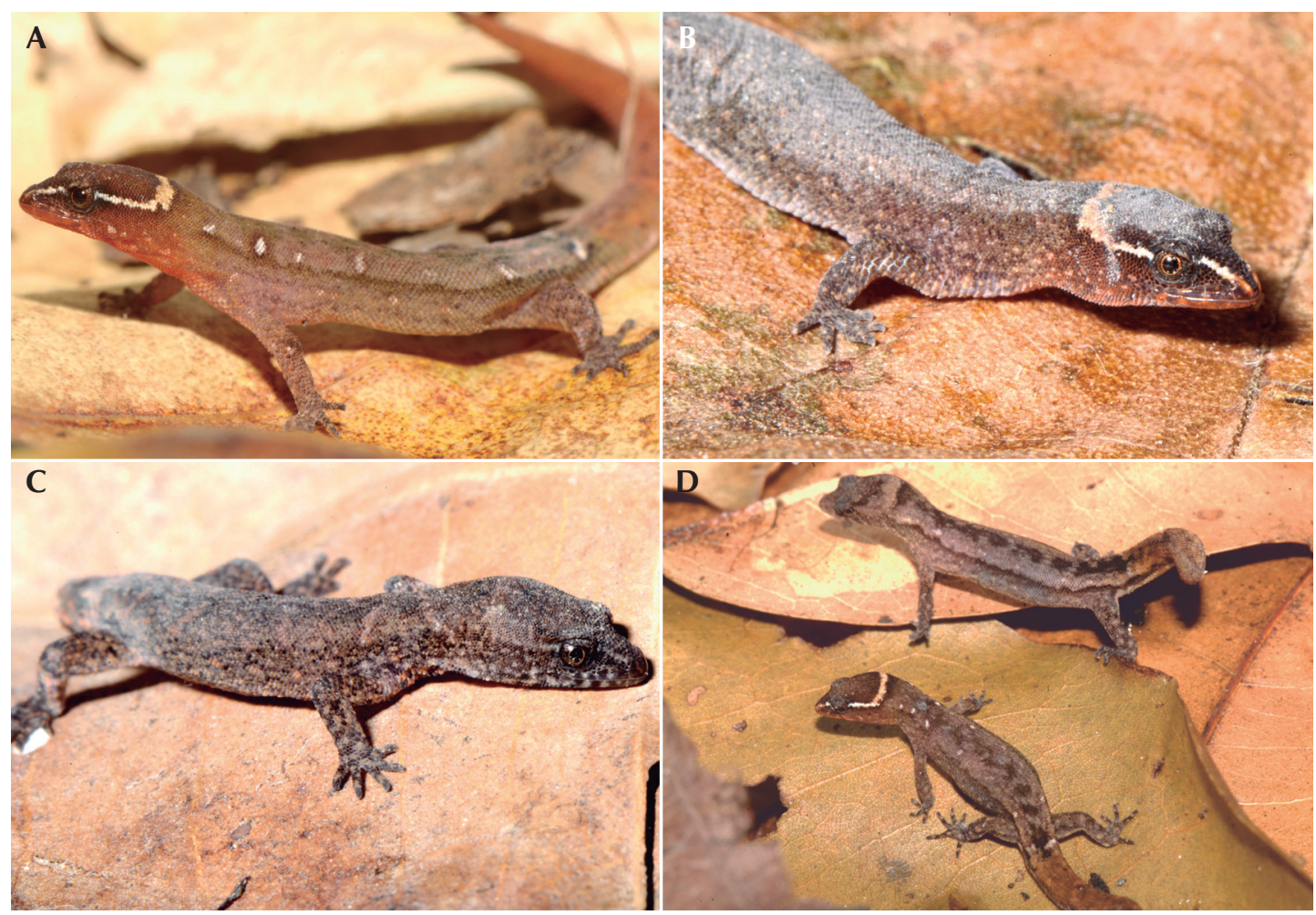

Figure 1. Lepidoblepharis miyatai: males (A, B) and female (C) from Concha Bay; (D) a couple from Las Tinajas Village. Santa Marta, Magdalena. Photographs by J. M. Renjifo. 
The lack of collected specimens and field observations led researchers to consider L. miyatai as Critically Endangered [CR B1ab (v) + 2ab (v)], or even possibly extinct (Ortega and Caicedo 2015). However, recently, CalderónEspinosa and Medina-Rangel (2015) were able to collect some specimens and add a new locality from the southeastern foothills of SNSM (Los Besotes Eco-park, Valledupar, Cesar Department), to its known distribution, which now allowed the species to be categorized as Endangered [EN B1 ab (i, iii)] based on its small distribution range $\left(1021 \mathrm{~km}^{2}\right)$, the age of most records, and highly endangered plant formations within its habitat.

The only herpetological study done near the type locality of Lepidoblepharis miyatai is the inventory of amphibians and reptiles of the "Ensenada Neguanje" (= Neguanje Bay; RuedaSolano and Castellanos-Barliza 2010), located about $3 \mathrm{~km}$ from Gairaca Bay, TNP. However, only the small gecko found was $L$. sanctaemartae (Ruthven, 1916) was found during that study (Figure 2A, B). Such information generated uncertainty regarding the distribution of $L$. miyatai, since its absence that close to its type locality was surprising. Moreover, it presented the possibility of sympatry between two congeners.

Small geckos choose optimal microhabitats for resources and crypsis (Vitt and Zani 1998). Several studies conducted in the Caribbean tropical dry forests (TDF) have shown that these reptiles are usually present at high densities (Ferrer and González 2007, Rueda-Solano and Castellanos-Barliza 2010, Medina-Rangel 2011, pers. obs.). Additionally, small geckos may constitute a significant contribution to the biomass and may be an important part of the energetic cycle of forests, but at present the evidence for these roles is lacking. Nothing is known of the ecology of L. miyatai. It is the purpose of this study to investigate the patterns of habitat use of L. miyatai, as well as to determine its distributional limits with respect to its congeners in northeastern Colombia.

\section{Materials and Methods}

\section{Study Area}

The present study was conducted in the northwestern foothills of SNSM, a series of low elevations that reach the sea, covered by TDF formations (Carbonó-De la Hoz and García-Q. 2010). This zone corresponds to the "Zonobioma Tropical Alternohígrico" (sensu HernándezCamacho and Sánchez 1992), showing a megathermal dry climate, with a large water deficit in the dry season. The rainfall regime is unimodal bi-seasonal, with an average annual precipitation of $608.8 \mathrm{~mm}$ (Rangel-Ch. and Carvajal-Cogollo 2012). During January 2016, we performed a field expedition to localities with confirmed presence of $L$. miyatai based on specimens deposited in the Magdalena University herpetological collection: two coastal localities, the "Ensenada Concha" (= Concha Bay, $11^{\circ} 17^{\prime} 18.94^{\prime \prime} \mathrm{N}, 74^{\circ} 08^{\prime} 56.79^{\prime \prime} \mathrm{W}$, $15 \mathrm{~m}$ a.s.1.) and Neguanje Bay $\left(11^{\circ} 18^{\prime} 23.61^{\prime \prime} \mathrm{N}\right.$, 7404'59.51" W; $19 \mathrm{~m}$ a.s.1.). These localities have a mosaic of thorn-scrub and TDF (SánchezHerrera et al. 2006); and additionally, another locality in the foothills, Las Tinajas Village $\left(11^{\circ} 16^{\prime} 12.49^{\prime \prime} \mathrm{N}, 74^{\circ} 04^{\prime} 10.88^{\prime \prime} \mathrm{W}\right.$; $372 \mathrm{~m}$ a.s.l.), in the TDF of the margins of Concha Creek (Sánchez-Herrera et al. 2006). At this locality, we obtained data about the abundance and habitat use of $L$. miyatai. We did not collect or manipulate specimens in TNP territory.

\section{Habitat Use}

In January 2014, we conducted a 12-day expedition to Las Tinajas Village, with the intention of observing Lepidoblepharis miyatai's microhabitat use. The lizard was detected using a Visual Encounter Survey (Crump and Scott 1994). Daily, two observers conducted random walks for six hours (8:00-11:00; 15:00-18:00) inside TDF fragments, actively looking for individuals in the available area. The total sampling effort was 72 hours per observer. We recorded the substrate just under the specimen at the time of sighting. 




Figure 2. Lepidoblepharis sanctaemartae: males from Manatí, Atlántico (A), and the TDF Permanent Plot at the Magdalena University, Santa Marta, Magdalena (B). Lepidoblepharis cf. sanctaemartae: male juvenile (C) and female (D) from La Batea, Middle Ranchería Basin, Albania, La Guajira. Photographs by J. M. Renjifo (A, D), L. P. Saboyá-Acosta (B) and J. D. Jiménez (C).

Information about available habitat was not measured, but we conduct an exploratory estimation of the sites used by the lizard. With the microhabitat data recorded, we performed a homogeneity Chi-square test for independent samples $\left(\chi^{2}\right)$, in order to test the null hypotheses stating no differential use of the microhabitats by L. miyatai. Expected values were calculated equitably from each substrate category detected in the field, assuming that all substrates had the same probability to be occupied, although not all are present with equal probability. Information about available habitat was not measured but also we present an estimation of the site used by the lizard at the first encounter.

\section{Distribution}

To determine the geographic distribution limits of Lepidoblepharis miyatai, we reviewed specimens of the genus Lepidoblepharis from northern Colombia and deposited in the Reptile Collection of Instituto de Ciencias Naturales (ICN-R) at the Universidad Nacional de Colombia (Bogotá, Colombia), the Reptile Collection at the Museo de Herpetología de la Universidad de Antioquia (MHUA-R, Medellín, Colombia), the Reptile Collection at the Centro de Colecciones Biológicas de la Universidad del Magdalena (CBMAG:REP) and Reptile Collection at the Instituto de Investigación en Recursos 
Biológicos Alexander von Humboldt (IAvH-R) attached to the Centro de Colecciones Biológicas de la Universidad del Magdalena (Santa Marta, Colombia). In addition, we complemented the review with Venezuelan specimens deposited in the Museo de la Estación Biológica Rancho Grande (EBRG, Maracay, Venezuela) and Museo de Biologia, Universidad de Zulia (MBLUZ, Maracaibo). For species level determination, we followed the characters of general lepidosis proposed by Lamar (1985), Batista et al. (2015), and Calderón-Espinosa and Medina-Rangel (2016). For subcaudal pattern nomenclature we followed Ávila-Pires (1995) and Rivero-Blanco and Schargel (2012). The distribution map was performed based on georeferences of localities from museum specimens. The locations of literature records are approximate.

\section{Results}

\section{Habitat and Microhabitat Use}

Lepidoblepharis miyatai is a species restricted to the dry ecosystems of the SNSM foothills. The species was only recorded in thorn-scrub and TDF vegetation. Although we do not have population data from all areas with confirmed presence of L. miyatai, field observations in Concha and Neguanje bays suggest that the species is more abundant in TDF than in other areas. The presence of the species was not confirmed in humid forests.

Based on data of microhabitat use from 88 individuals recorded in Las Tinajas Village TDF, we determined three categories of substrate used by L. miyatai (Table 1): leaflitter, fallen trunks and bare floor. A differential use of available substratum $\left(\chi^{2}=93.70, d f=2\right.$; $p<0.001$; Figure 3 ) is evident. Comparing the expected with observed frequency for each cell of habitat use indicated a significantly high level of use of leaf-litter $(82 \%)$ and use of the other substrates that was not significantly different from expectation (fallen trunks: $12.50 \%$; bare floor: $5.68 \%$ ).

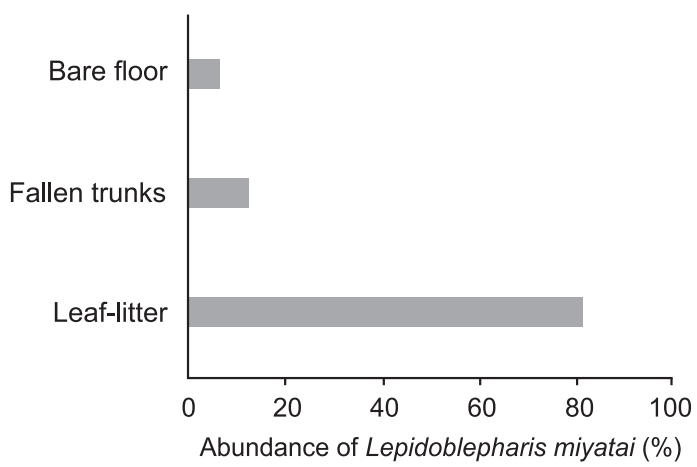

Figure 3. Habitat use proportion by Lepidoblepharis miyatai from Las Tinajas Village.

Table 1. Microhabitat use and $\chi^{2}$ values for each one. *Degrees of freedom $=2, p<0.001$.

\begin{tabular}{lcc}
\hline Substrata & Individuals & $\chi^{2}$ \\
\hline Leaf-litter & 72 & 62.061 \\
Fallen trunks & 11 & 11.458 \\
Bare floor & 5 & 20.186 \\
\hline Total & $\mathbf{8 8}$ & $\mathbf{9 3 . 7 0 5 *}^{*}$ \\
\hline
\end{tabular}

\section{Distribution of Lepidoblepharis Species of the} Northern Colombia

The distribution of Lepidoblepharis miyatai is restricted to the northwestern sector of SNSM foothills (Figure 4). We present four new localities with confirmed presence of $L$. miyatai in TNP and their adjacent buffer zone, based on collection specimens and field observations. The westernmost locality is Concha Bay, located $5.34 \mathrm{~km}$ southwest from the type locality. The nearest record to the type locality is Neguanje Bay, located $2.73 \mathrm{~km}$ southeast from Gairaca Bay. The southernmost locality is Las Tinajas Village, at $6.32 \mathrm{~km}$ in straight line to southeast. Calculating the extent of occurrence of $L$. miyatai, we obtained an area of $21.3 \mathrm{~km}^{2}$, and altitudinal range from sea level to $370 \mathrm{~m}$ a.s.l. 
approximately. In none of the sampled localities, did we record sympatry of $L$. miyatai with other Lepidoblepharis.

The distribution of Lepidoblepharis miyatai is flanked to the south-west by the distribution range of $L$. sanctaemartae. Just $8.49 \mathrm{~km}$ from the westernmost locality of the $L$. miyatai distribution, there is a locality with confirmed presence of $L$. sanctaemartae: the periurban remnant forest associated with the lower Manzanares Basin (Magdalena University, urban center of Santa Marta, Magdalena). There are additional specimens from the middle Manzanares Basin (Bonda Village, Santa Marta, Magdalena), recorded $6.49 \mathrm{~km}$ southwest from Las Tinajas Village. When advancing towards south throughout the western foothills of the SNSM, there are more localities with confirmed presence of $L$. sanctaemartae: in the Gaira Basin (Puerto Mosquito Village, Santa Marta, Magdalena), Córdoba Basin (Cordobita Village, Ciénaga, Magdalena), Sevilla Basin (Prado Sevilla Village, Zona Bananera, Magdalena), and Fundación Basin (Fundación, Magdalena, type locality).

In our revision of museum specimens of Lepidoblepharis from the Colombian Caribbean, we detected a morph of this genus that until now has not been determined at the species level (hereafter, named Lepidoblepharis cf. sanctaemartae; Figure 2C, D). This morph shares with $L$. sanctaemartae the large, flattened, and overlapping dorsal scales; and the posterior margin of mental scale with a medial cleft; but it differs in number of fourth toe lamellae $(L$. sanctaemartae: 8-9vs L. cf. sanctaemartae: 1012); and subcaudal scale pattern which, according to the coding method proposed by Ávila-Pires (1995) and Rivero-Blanco and Schargel (2012) L. sanctaemartae corresponds to type B, 1'1'1', $v s$. cf. sanctaemartae that is type E. Likewise, it has evident differences with L. miyatai, which has swollen, raised and subimbricate dorsal scales; posterior margin of mental scale without cleft; and the subcaudal scale pattern is a 1'1' continuous sequence (no type of subcaudal pattern with this configuration has been described).

Lepidoblepharis cf. sanctaemartae is distributed in the east of SNSM, including valleys of the Cesar River and Ranchería River. The closest record of Lepidoblepharis cf. sanctaemartae to L. miyatai corresponds to the specimen ICN-R 12791, collected in the lower Ancho River (Río Ancho Village, Dibulla, La Guajira), at $56.8 \mathrm{~km}$ from easternmost point of L. miyatai distribution. Likewise, the specimens cited previously as L. miyatai, MHUA-R 10996-10997 from Los Besotes Eco-park (Valledupar, Cesar), also correspond to $L$. cf. sanctaemartae. When excluding this locality, the extent of occurrence of $L$. miyatai is reduced from 1021 to $21.3 \mathrm{~km}^{2}$. The limits among distribution ranges of $L$. miyatai and $L$. cf. sanctaemartae are still uncertain, and points where populations of both taxa overlap (eventuality) are unknown.

\section{Discussion}

\section{Habitat and Microhabitat Use}

The presence and abundance of small geckos is mainly determined by habitat conditions since many of their species have very precise habitat requirements (Vitt et al. 2005). Vegetation structure determines environmental variables such as light penetration, leaf-litter depth and humidity, these factors could be required for the presence of Lepidoblepharis (Angarita-M. et al. 2015). For example, the forest fragments provide the ideal conditions of humidity and temperature for a high relative abundance of $L$. sanctaemartae, with is also directly related to the area of the fragment (Carvajal-Cogollo and Urbina-Cardona 2008).

The distribution of Lepidoblepharis miyatai overlaps with the dry formations of the TNP, which are the best conserved TDF relicts in Colombia (Cuadros and Idárraga 2014). RuedaSolano and Castellanos-Barliza (2010) pose the presence of $L$. miyatai in TDF, thorn-scrub and 


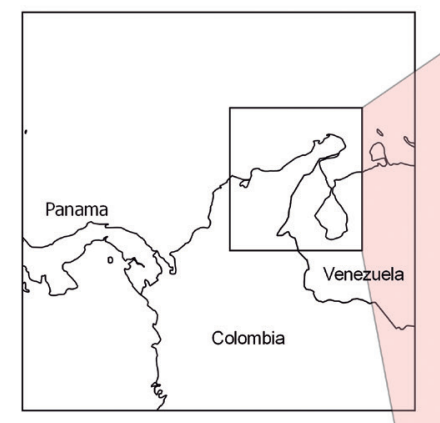

\section{Legend}

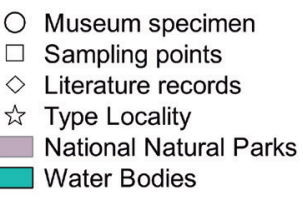

SRC: MAGNA - EPSG: 4686 Projection: Gauss krugger Cartography: 1:400.000

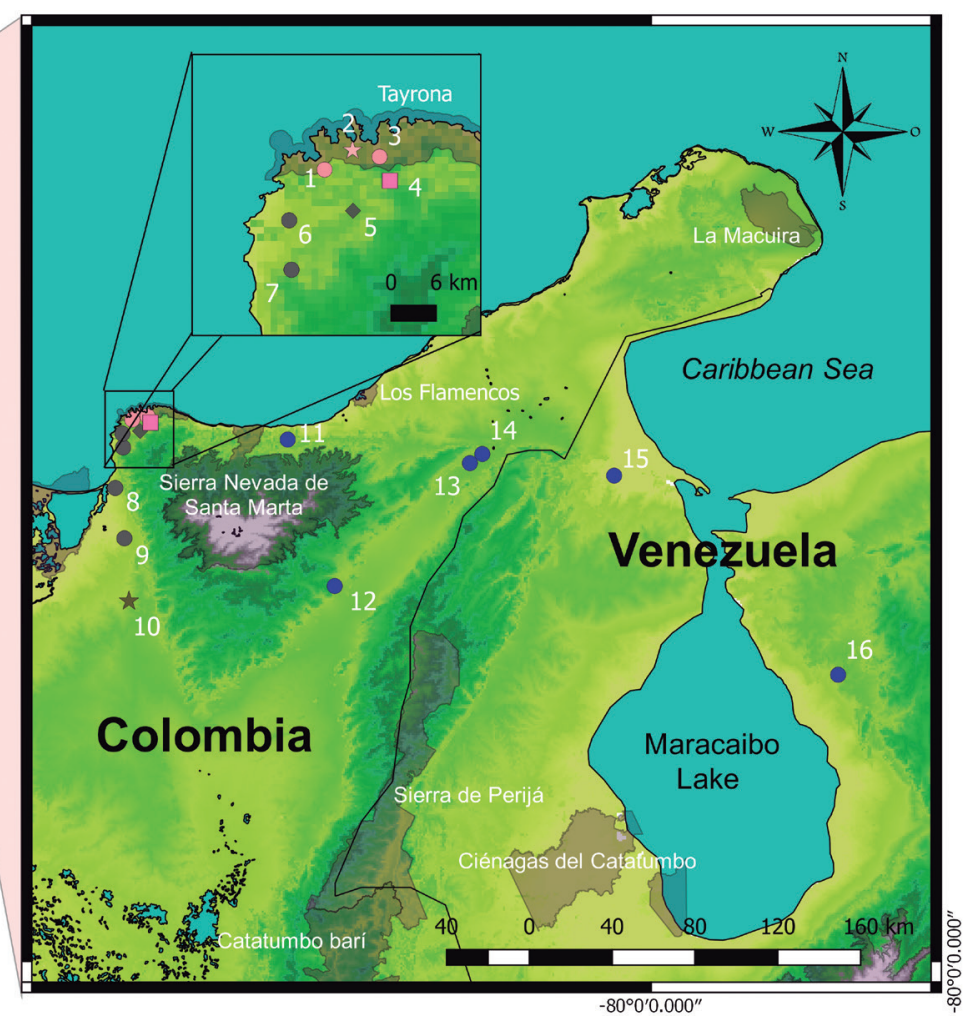

Figure 4. Distribution of Lepidoblepharis species from northeastern Colombia. Lepidoblepharis miyatai (pink): 1. Concha Bay, 2. Gairaca Bay (type locality), 3. Neguanje Bay, 4. Las Tinajas Village. Lepidoblepharis sanctaemartae (gray): 5. Bonda Village (record by Lamar 1985), 6. TDF Permanent Plot at the Magdalena University, 7. Puerto Mosquito Village, 8, Cordobita Village, 9. Sevilla Village, 10. Fundación (type locality). Lepidoblepharis cf. sanctaemartae (blue): 11. Río Ancho Village, 12. Los Besotes Eco-Park, 13. Ranchería River (La Batea), 14. Bruno Creek, 15. Guasare River, 16. Burro Negro Dam.

xerophilous scrub. Nevertheless, we consider the presence of the species in xerophilous scrub unlikely, since this vegetation is dominated by setaceous plants and shows sparse canopy, preventing the formation of a leaf-litter layer and allowing almost total penetration of sunlight on the rocky substrate. Like other small geckos, L. miyatai avoids direct exposure to sunlight (Montes-Correa pers. observ.). Small geckos usually prefer shady places (Lisboa and Freire 2012), probably because corporal temperature of these lizards strongly depends on substrate temperature due to their small size (Vitt et al.
2005). The rocky matrix without leaf-litter of the low coastal mountains where xerophytic scrub grows greatly reduces the probability of establishment of L. miyatai. Surely, the presence of this lizard is favored by continuous forest coverage, but like $L$. sanctaemartae, it can also occupy edge zones (Carvajal-Cogollo and Urbina-Cardona 2015).

For certain gecko species such as Chatogekko amazonicus (Andersson, 1918) and some Coleodactylus Parker, 1926, it has been shown that although they may use a wide range of microhabitats, they have a marked preference for 
leaf-litter (Vitt et al. 2005, Werneck et al. 2009, Lisboa and Freire 2012). Although most of the specimens of L. miyatai detected in the field use available leaf litter, it is not possible to determine if the species prefers this substrate, since there is no information on the availability of microhabitat and its relation to use by this lizard.

However, not to be discounted a possible microhabitat use variation to $L$. miyatai, since when the availability of resources changes, the proportion of resource use is likely to vary (Vitt et al. 2007). For example, Gymnodactylus amarali Barbour, 1925 favors heavily rupicolous habits in savannahs and eats a diet composed principally of termites (Colli et al. 2003). On the other hand, Werneck et al. (2009) state that $G$. amarali has the widest range of microhabitat uses in TDF, given the lower availability of rocky substrate and the lack of epigeous termite nests. For L. miyatai, although we only record information in TDF, it is expected to maintain this pattern of variation in habitat use depending on the food resource availability provided by other plant cover such as thorn-scrub and humid forest.

Distribution of Lepidoblepharis Species of the Northern Colombia

Despite substantial morphological differences between $L$. sanctaemartae and $L$. miyatai, two previous investigations in the TNP misidentified L. miyatai. Lugo-Rugeles (1981) presented observations about reproductive behavior of $L$. miyatai under the name $L$. sanctaemartae. This investigation was made before the original description of L. miyatai. Lamar (1985) clarified that the specimens cited by Lugo-Rugeles (1981) corresponded to L. miyatai. The second study where L. miyatai was erroneously determined as L. sanctaemartae was Rueda-Solano and Castellanos-Barliza (2010), who investigated the herpetofauna of Neguanje Bay. In our study we determined that all observed small geckos and the specimen CBUMAG:REP:00303 cited by the aforementioned authors belong to L. miyatai.
The reduced distribution of $L$. miyatai presented in our study suggest this species is endemic to the northwestern foothills of the SNSM. Although, we do not know any locality where L. miyatai and L. sanctaemartae are in sympatry, this possibility should not be discounted given the currently know distribution limits of both species. There is a locality with an exclusive presence of $L$. sanctaemartae in the peri-urban TDF of Santa Marta (Montes-Correa et al. 2015), which is very close to the peripheral localities of the L. miyatai distribution. The sympatry between some small geckos such as L. xanthostigma (Noble, 1916) and $L$. victormartinezi Batista, Ponce, Vesely, Mebert, Hertz, Köhler, Carrizo, and Loztkat, 2015 in Panama has been reported previously (see specimens examined by Batista et al. 2015; A. Batista pers. comm.). Other species like $C$. amazonicus and Coleodactylus meridionalis (Boulenger, 1888) in the Brazilian Amazon share part of their geographical distribution and microhabitat, but they separate in their trophic niche (Vitt et al. 2005). In the case of L. miyatai, if the presence of $L$. sanctaemartae excludes it, the distribution of this small gecko probably does not extend much further south than reported by us.

Regarding the record of Lepidoblepharis miyatai southwest of the SNSM, the specimens MHUA-R 10996-10997 from Los Besotes Ecopark (Valledupar, Cesar), cited by CalderónEspinosa and Medina-Rangel (2015, 2016), do not correspond to this species. Most likely, they are $L$. cf. sanctaemartae (see characters described in Results section). In previous studies in the same area, this population was designated as $L$. sanctaemartae (Rueda-Almonacid et al. 2008). The specimens named $L$. sanctaemartae by Blanco-Torres et al. (2013) in the middle Ranchería Basin (eastern foothills of the SNSM), also correspond to $L$. cf. sanctaemartae. This species inference was confirmed after studying the specimens CBUMAG:REP:00305 and CBUMAG:REP:00306-11 from Arroyo Bruno (= Bruno Creek, a tributary of the Ranchería 
River) and La Batea (sector of the middle Ranchería Basin) respectively, from Albania, La Guajira. Likewise, it is possible that the specimens reported by Rivas et al. (2002) from the Guasare River, eastern versant of the Serranía de Perijá, Estado Zulia, Venezuela, as well as an isolated population from the eastern side of the Maracaibo Lake basin can also be assigned to $L$. cf. sanctaemartae. Studies to clarify the status of these populations are currently under development by the authors.

Given that recent assessments of conservation status of $L$. miyatai only include either the type locality (Ortega and Caicedo 2015) or localities where the species is not present (CalderónEspinosa and Medina-Rangel 2015), a reevaluation is required. Nevertheless, we refrain from suggesting a new categorization with the IUCN criteria, because the potential extent of occurrence and population status of L. miyatai is still unknown. For a precise assessment of the conservation status, the delimitation of distribution limits and evaluation of population attributes of L. miyatai is needed.

\section{Acknowledgments}

This contribution is a result of the project "The small world of Lepidoblepharis miyatai: taxonomic-ecological relationships as conservation tools", financed by by EDGE program of Zoological Society of London (ZSL) and Fondation Segré, and supported by Universidad del Magdalena, Santa Marta, Colombia. We thanks to Juan Carlos Dib for allowing us to make observations in Kalashe Kalabria Reserve, in Las Tinajas Village; to Luz Adriana Velazco for allowing us to make observations in $\mathrm{La}$ Iguana Verde Reserve, in Puerto Mosquito; and Carlos "Cayito" Fernández for allowing us to make observations in La Escuela de la Naturaleza Reserve. Special thanks go to Adolfo del Portillo, Richard Thomas, Adriana Santodomingo, Alina Gámez, Sintana Rojas, Jefferson Villalva, Harold Cuello, José Barros, Alexandra Ramírez, Raiza Castañeda, and Oskarly Pérez for their field assistance. To German Blanco and the Histology Class 2013-2 at Magdalena University, with whom ACMC met L. miyatai. ACMC and JDJB are grateful with Miguel Gutiérrez and Alex González for their help with specimen collections in the eastern sector of the SNSM. Thanks to curators of ICN, MHUA, EBRG, MBLUZ, and CBUMAG for allowing us to review their voucher specimens. We are grateful to Myriam Lugo-Rugeles, Abel Batista, and Konrad Mebert for providing additional information about their research. Finally, thanks to Lorena Benítez, Andrea Cotes, Jorge M. González, Claudia Koch, William W. Lamar, Junior Larreal, Franziska Leonhardt, and José Ángel Rincón for their invaluable comments on the manuscript. The collecting activities were legally permitted under Permiso Marco de Recolección de Especímenes Number 0255, Universidad Nacional de Colombia-Ministerio del Medio Ambiente y Desarrollo Sostenible.

\section{References}

Andersson, L. G. 1918. New lizards from South America. Collected by Nils Holmgren and A. Roman. Arkiv för Zoologi 11: 1-9.

Angarita-M., O, A. C. Montes-Correa, and J. M. Renjifo. 2015. Amphibians and reptiles of an agroforestry system in the Colombian Caribbean. Amphibian \& Reptile Conservation 8: 33-52.

Armesto, L. O. and J. C. Señaris. 2017. Anuros del norte de los Andes: patrones de riqueza de especies y estado de conservación. Papéis Avulsos de Zoologia 57: 491-526.

Ávila-Pires, T. C. S. 1995. Lizards of Brazilian Amazonia (Reptilia: Squamata). Zoologische Verhandelingen Leiden 299: 1-706.

Ayala, S. C. 1986. Saurios de Colombia: lista actualizada, y distribución de ejemplares colombianos en los museos. Caldasia 15: 555-575.

Ayala, S. C. and M. A. Serna. 1986. Una nueva especie de Lepidoblepharis (Sauria, Gekkonidae) de la Cordillera Central de Colombia. Caldasia 15: 649-654.

Barbour, T. 1925. New Neotropical lizards. Proceedings of the Biological Society of Washington 38: 101-102. 
Batista, A., M. Ponce, M. Vesely, K. Mebert, A. Hertz, G. Köhler, A. Carrizo, and S. Lotzkat. 2015. Revision of the genus Lepidoblepharis (Reptilia: Squamata: Sphaerodactylidae) in Central America, with the description of three new species. Zootaxa 3994: 187-221.

Blanco-Torres, A, L. Báez, E. Patiño-Flores, and J. M. Renjifo. 2013. Herpetofauna del valle medio del río Ranchería, La Guajira, Colombia. Revista de Biodiversidad Neotropical 3: 113-122.

Boulenger, G. A. 1888. On some reptiles and batrachians from Iguarasse, Pernambuco. The Annals and Magazine of Natural History, Zoology, Botany, and Geology 2: $40-43$

Calderón-Espinosa, M. L. and G. F. Medina-Rangel. 2015. Lepidoblepharis miyatai Lamar, 1985. Pp. 58-60 in M A. Morales-Betancourt, C. A. Lasso, V. P. Páez, and B. C. Bock (eds.), Libro Rojo de Reptiles de Colombia. Bogotá. Instituto de Investigación de Recursos Biológicos Alexander von Humboldt (IAvH), Universidad de Antioquia.

Calderón-Espinosa, M. L. and G. F. Medina-Rangel. 2016. A new Lepidoblepharis lizard (Squamata: Sphaerodactylidae) from the Colombian Guyana shield. Zootaxa 4067: 215-232.

Carbonó-De la Hoz, E. and H. García-Q. 2010. La vegetación terrestre en la ensenada de Neguanje, Parque Nacional Natural Tayrona (Magdalena, Colombia). Caldasia 32: $235-256$.

Carvajal-Cogollo, J. E. and J. N. Urbina-Cardona. 2008. Patrones de diversidad y composición de reptiles en fragmentos de bosque seco tropical en Córdoba, Colombia. Tropical Conservation Science 1: 397-416.

Carvajal-Cogollo, J. E. and J. N. Urbina-Cardona. 2015. Ecological grouping and edge effects in tropical dry forest: reptile-microenvironment relationships. Biodiversity and Conservation 24: 1109-1130.

Carvajal-Cogollo, J. E., G. Cárdenas-Arévalo, and O. V. Castaño-Mora. 2012. Reptiles de la Región Caribe de Colombia. Pp. 791-812 in J. O. Rangel-Ch (ed.), Colombia Diversidad Biótica XII: La Región Caribe de Colombia. Bogotá. Instituto de Ciencias Naturales, Universidad Nacional de Colombia.

Colli, G. R., D. O. Mesquita, P. V. V. Rodrigues, and K. Kitayama. 2003. Ecology of the gecko Gymnodactylus geckoides amarali in a Neotropical savanna. Journal of Herpetology 37: 694-706.

Crump, M. L. and N. J. Scott. 1994. Visual encounter surveys. Pp. 84-92 in W. R. Heyer, M. A. Donnelly, R. W. McDiarmid, L. Hayek, and M. S. Foster (eds.), Measuring and Monitoring Biological Diversity, Standard Methods for Amphibians. Washington D.C. Smithsonian Institution Press.
Cuadros, H. and A. Idárraga. 2014. La costa Caribe. Pp. 74 in C. Pizano and H. García (eds.), El Bosque Seco Tropical en Colombia. Bogotá. Instituto de Investigación de Recursos Biológicos Alexander von Humboldt (IAvH), Ministerio de Ambiente y Desarrollo Sostenible.

Ferrer, J. and M. González. 2007. Supervivencia de los saurios del Jardín Botánico de Barranquilla. Revista Colombiana de la Academia de Ciencias Exactas, Físicas y Naturales 31: 139-144.

Hernández-Camacho, J. I. and H. Sánchez. 1992. Biomas terrestres de Colombia. Pp. 153-174 in G. I Halffter (ed.), La Diversidad Biológica de Iberoamérica. México D.F. CYTED-D, Acta Zoológica Mexicana.

Lamar, W. W. 1985. A new Lepidoblepharis (Sauria: Gekkonidae) from the north coast of Colombia. Herpetologica 41: 128-132.

Lisboa, C. M. C. A. and E. M. X. Freire. 2012. Population density, habitat selection and conservation of Coleodactylus natalensis (Squamata: Sphaerodactylidae) in an urban fragment of Atlantic Forest in northeastern Brazil. South American Journal of Herpetology 7: $181-190$.

Lugo-Rugeles, M. 1981. Notas sobre el comportamiento del geco Lepidoblepharis sanctaemartae sanctaemartae (Reptilia, Lacertilia, Gekkonidae). Boletín del Departamento de Biología de la Universidad Nacional del Colombia 3: 19-23.

Lynch, J. D., P. M. Ruiz-Carranza, and M. C. Ardila-Robayo. 1997. Biogeographic patterns of Colombian frogs and toads. Revista de la Academia Colombiana de Ciencias Exactas, Físicas y Naturales 21: 237-248.

Medina-Rangel, G. F. 2011. Diversidad alfa y beta de la comunidad de reptiles en el complejo cenagoso de Zapatosa, Colombia. Revista de Biología Tropical 59: 935-968.

Montes-Correa, A. C., J. D. Jiménez-Bolaño, D. VergaraRíos, Y. Ávila-Silva, L. P. Saboyá-Acosta, and J. M. Renjifo. 2015. Herpetofauna del campus de la Universidad del Magdalena, Santa Marta, Colombia. Revista de Biodiversidad Neotropical 5: 54-63.

Noble, G. K. 1921. The bony structure and phyletic relations of Sphaerodactylus and allied lacertilian genera, with the description of a new genus. American Museum Novitates 4: 1-16.

Ortega, A. and J. Caicedo. 2015. Lepidoblepharis miyatai. The IUCN Red List of Threatened Species 2015, e. T44579408A44579411. Eletronic Database accessible at http://dx.doi.org/10.2305/IUCN.UK.2015-4.RLTS. T44579408A44579411.en. Captured on 28 January 2017.

Parker, H. W. 1926. The Neotropical lizards of the genera Lepidoblepharis, Pseudogonatodes, Lanthrogecko, and 
Sphaerodactylus, with the description of a new genus. The Annals and Magazine of Natural History, Zoology, Botany, and Geology 17: 291-301.

Peracca, M. G. 1897. Viaggio del Dr. Enrico Festa nell'Ecuador e regioni vicine. IV. Rettili. Bollettino dei Musei di Zoologia e di Anatomia Comparata della $R$. Università di Torino 12: 1-20.

Rangel-Ch., J. O. and J. E. Carvajal-Cogollo. 2012. Clima de la región Caribe colombiana. Pp. 67-129 in J. O. Rangel-Ch. (ed.), Colombia Diversidad Biótica XII: La Región Caribe de Colombia. Bogotá. Instituto de Ciencias Naturales, Universidad Nacional de Colombia.

Rivas, G., J. Manzanilla, R. Rivero, and E. La Marca. 2002. Lepidoblepharis sanctaemartae (Ruthven, 1916), a lizard new to the Venezuelan fauna. Herpetozoa 15: 92-94.

Rivero-Blanco C., and W. E. Schargel. 2012. A strikingly polychromatic new species of Gonatodes (Squamata: Sphaerodactylidae) from northern Venezuela. Zootaxa 3518: 66-78.

Rueda-Almonacid, J. V., A. A. Velásquez, P. A. Galvis, and J. Gualdrón-Duarte. 2008. Reptiles. Pp. 193-268 in J. V. Rodríguez-Mahecha, J. V. Rueda-Almonacid, and T. D. Gutiérrez-Hinojosa (eds.), Guía Ilustrada de Fauna del Santuario de Vida Silvestre Los Besotes, Valledupar, Cesar, Colombia. Bogotá D. C. Serie de guías tropicales de campo $\mathrm{N}^{\mathrm{o}} 7$, Conservación Internacional, Editorial Panamericana, Formas e Impresos.

Rueda-Solano, L. A. and J. Castellanos-Barliza. 2010. Herpetofauna de Neguanje, Parque Nacional Natural
Tayrona, Caribe colombiano. Acta Biológica Colombiana 15: $195-206$.

Ruthven, A. G. 1916. A new genus and species of lizard from Colombia, with remarks on the genus Pseudogonatodes. Occasional Papers of the Museum of Zoology 21: 1-4.

Sánchez-Herrera, G., M. L. Hernández-Turriago, G. MayorAragón, C. Gómez-Rangél, I. P. Corredor-Bobadilla, M. Y. Bridges-Amaya, W. Blanco-Ortíz, M. Muñoz-Díaz, J. M. Pinzón-Cáceres, and R. Franke-Ante. 2006. Plan de Manejo, Parque Nacional Natural Tayrona. Santa Marta. Parques Nacionales de Colombia, Dirección Territorial Caribe. 298 pp.

Vitt, L. J. and P. A. Zani. 1998. Ecological relationships among sympatric lizards in a transitional forest in the northern Amazon of Brazil. Journal of Tropical Ecology 14: 63-86.

Vitt, L. J., S. S. Sartorius, T. C. S. Ávila-Pires, P. A. Zani, and M. C. Espósito. 2005. Small in a big World: ecology of leaf-letter geckos in the New World tropical forest. Herpetological Monographs 19: 137-152.

Vitt, L. J., G. R. Colli, J. P. Caldwell, D. O. Mesquita, A. A. Garda, and F. G. R. França. 2007. Detecting variation in microhabitat use in low-diversity lizard assemblages across small-scale habitat gradients. Journal of Herpetology 41: 654-663.

Werneck, F. P., G. R. Colli, and L. J. Vitt. 2009. Determinants of assemblage structure in Neotropical dry forest lizards. Austral Ecology 34: 97-115.

Editor: Steven Poe

Appendix I. Material examined.

Lepidoblepharis miyatai. COLOMBIA. Magdalena: Santa Marta: Ensenada Concha, afueras del Parque Nacional Natural Tayrona (CBUMAG:REP:00302, ICN-R 12795); Ensenada Neguanje, Parque Nacional Natural Tayrona (CBUMAG:REP:00303); Reserva Kalashe Kalabria, Las Tinajas (CBUMAG:REP:00304).

Lepidoblepharis sanctaemartae. COLOMBIA. Atlántico: Manatí: Finca Los Mamones, (CBUMAG: REP:00264-7). Magdalena: Santa Marta: Parcela permanente de bosque seco de la Universidad del Magdalena (ICN-R 12766-12773); Sena Agropecuario de Gaira (IAvH-R-6693-6696); Reserva La Iguana Verde, Vereda Puerto Mosquito (ICN-R 12783-12790); Girocasaca, Bonda, Magdalena (ICN-R 12792-12793); Ciénaga: Finca El Recuerdo, Vereda Cordobita (ICN-R 12774-12782); Zona Bananera: Prado Sevilla (ICN-R. 12794). SucRE: San Onofre: Afueras del Parque Nacional Natural Labarcé (CBUMAG:REP:00285-92).

Lepidoblepharis cf. sanctaemartae. COLOMBIA. CESAR: Valledupar: Reserva Forestal Protectora Los Besotes (MHUA-R 10996-10997, ICN-R 12797-12799). La GuAJRA: Dibulla: Escuela de La Naturaleza, Río Ancho (ICN-R 12791); Albania: Tramo del Ranchería sector La Batea (CBUMAG:REP:00306-11), Arroyo Bruno (CBUMAG:REP:00305). VENEZUELA. Estado Zulia: Rio Guasare, Sierra de Perijá (EBRG 3318-3320, 3324, 3326-3328); Embalse de Burro Negro (EBGR 2022, MBLUZ 1436-1437). 